\title{
The Relationship between Adolescent Development and Marriage in Cirendeu Village, District East Ciputat, South Tangerang, Banten Province of Indonesia
}

\author{
Djawahir Hejazziey $^{1}$ \\ ${ }^{1}$ Lecturer Fakultas Syariah dan Hukum Universitas Islam Negeri, Jakarta, Indonesia \\ Correspondence: Djawahir Hejazziey, Fakultas Syariah dan Hukum Universitas Islam Negeri, Jakarta, Indonesia. \\ E-mail: djawahirh01@gmail.com
}

Received: December 22, 2015

Accepted: January 10, 2016 Online Published: February 1, 2016

doi:10.5539/ijps.v8n1p162

URL: http://dx.doi.org/10.5539/ijps.v8n1p162

\begin{abstract}
The aim in this study is to describe the adolescent development and marriage, this time quite contrary to marriage is based on the religion of Islam. This study uses a analisis quantitative, approach deskripitif and inferential analysis. The normality test analysis, correlation, regression analysis and uses Test-T. Sample is adolescents (residents) in the village Cireundeu, District East Ciputat, South Tangerang, Banten province. The total sample is 150 people. The results showed that there is a relationship between adolescent development and marriage. It is seen from a wedding going on in teenagers is not only formed from adolescent development, but also of other factors. It can be concluded that the marriage occurred among adolescents is one of the developments of promiscuity with their peers. This promiscuity occurs because of lack of understanding and knowledge of adolescents to promiscuity and a lack of understanding of the value of religion. Religious educations in adolescents to be conducted if want to changes in behavior and personality.
\end{abstract}

Keywords: adolescent development, regulatory, marriage

\section{Introduction}

Adolescence takes place between the ages of 12 years to 21 years for women and 13 years up to 22 years for men. In adolescence in addition to the period of beautiful, it is also the period of a vulnerabl. At this age, adolescents are prone to get into trouble in his life such as drug abuse, promiscuity, conflict with family, smoking, and so on.

According Darajat (1995) adolescence is a period of transition between childhood and adulthood. In this period, the children experienced a period of growth and development period of physical and psychological development. They are not children, either in body shape or way of thinking or acting, but not adults who have matured.

Santrock (2003) stated that adolescence is defined as the future development of transition between childhood and adulthood that include changes in the biological, cognitive, and social-emotional. Poerwadarminta (1984) which states adolescence are: (1) Start the adults; had reached the age for mating, (2) Young (about boys and girls); began to emerge love, lust. Although this concept looks simple but it at least illustrates in part from understanding teens. In adolescence are particularly vulnerable to the association that is banned by religion, promiscuity occurred due to the influence of globalization that occurred during this time, when the freedom of associating has reached the level that is worrying. Many behaviors are negative, which happens to teenagers this time, like; liquor, consume drugs, free sex, and others that can cause the spread of HIV/AIDS. This situation is very alarming, because teenagers become the backbone of the nation, which is expected to work in the future.

Early marriage is a form of bond or a marriage in which one or both spouses under the age of 18 years or are studying the school and still included in the category of adolescence. So a marriage called early marriage, if both or one partner is still under 18 years old which is still adolescence.

The adolescence of early marriage is regarded as a way out to avoid sin, namely free sex. Early marriages are conducted, due to adolescents experiencing the pressures of life, and adolescents are still in a period of instability that is filled with turmoil, it is not rare fatal to early marriage. Early marriages performed in adolescence due to various reasons are economic factors, minimize promiscuity, ambition, and pregnant outside of marriage. 
The phenomenon of adolescence marriage or early marriage is common and received considerable attention among caregivers of children and adolescents. Early marriage is a common phenomenon in developing countries such as in South Asia, Southeast Asia, Africa, and Latin America (Mcintyre, 2006). Boykin and Stitch (2007) suggested that the tendency of marriage in adolescence led to distress and ended in separation, in which the main cause is the least experience and factors lack of preparedness in the face of marriage.

Research Choe, Thapa, and Ahmad (2007) (in the Early Marriage and childbearing in Indonesia and Nepal, 1999) in terms of demographics shows that marriage before the age of 18 generally occurs in women in Indonesia mainly rural region. This is because the level of the economy and low education in rural areas in Indonesia as well as factors that inadequate access to information.

Indonesia is among countries with the percentage of marriages young age the highest in the world (rank 37), in 2010 , there were 158 countries with age of legal marriage age is 18 years and above, and Indonesia are not included therein (UNICEF, 2011). The province with the percentage early marriage (15-19 years) is the highest in Central Kalimantan (52.1\%), West Java (50.2 percent), and South Kalimantan (48.4\%), Pacific Islander (47.9\%) and Central Sulawesi (46. 3\%) (RISKESDAS, 2010).

Indonesia is among countries with the percentage of marriages young age high in the world (rank 37), in 2010, there were 158 countries with age minimum legal marriage is 18 years and above, and Indonesia are not included therein (UNICEF, 2011). The province with the percentage of early marriages (15-19 years) is highest in Central Kalimantan (52.1\%), West Java (50.2 percent), and South Kalimantan (48.4\%), the Pacific Islands (47.9\%) and Central Sulawesi (46.3\%) (RISKESDAS, 2010).

In Indonesia indicates that early marriage occurs as a solution to pregnancy outside of marriage (premarital pregnant) (Bannet, 2001; Gupta, 2000). Early marriage (early marriage) have the same impact on young women and young men. These impacts include the effects of physical, intellectual, and emotional (UNICEF, 2001). Men who marry at a young age usually experience stress related to their new role as husband and father (Papalian \& Olds, 1995).

Women who marry at a young age or young women who were married to experience a greater impact than men who married at a young age, it relates to various forms of readiness to prepare adolescent girls who marry young (Papalia \& Old, 1995). The readiness with regard to readiness physically and mentally, physically associated with pregnancy and childbirth, while mentally related to experiences that are usually gained by young people in general. The experience was like continuing education, get good health care jobs and economic opportunities and friendships with peers (UNICEF, 2001).

Early marriage can also make young women become isolated from family and friends when they should stay with her husband (WHO, 2006). Similarly, says Mathur et al. (2003) greatly reduces the chance of early marriage of young women to gain access to education, thus reducing their chances of getting a better job to help the family economy.

Various problems had a negative impact on the development of adolescents themselves. It is also due to the actual development task in adolescence than it should be accelerated, early marriages performed adolescents require adolescents to prepare at this stage of marriage and family. Adolescents who get married will enter adulthood, called adolescence shortened, so that the characteristics and development tasks is also changing (Monks, 2001).

Hurlock (1999), said in adolescence that they have to meet are still at the stage of preparation for marriage and family, have not yet entered the stage of the actual wedding is that the task of development at present. Developmental task in adolescence is focused on tackling the attitudes and behavior patterns childish and preparing to face adulthood that one of them is preparing for marriage and family (Hurlock, 1999).

This research is important because look at the percentage of adolescents who turns age marriages are still common and then have a significant impact for the development of adolescents, especially girls (WHO, 2006). Therefore, in this study the researchers wanted to know adolescent development, and marriage, as well as the regulation of marriage is based on the Islamic religion as seen from the teenage demographic is (gender). Thus the question in this research specifically is whether there are differences in adolescent development towards marriage? How the relationship of between the development of adolescents and marriage? 


\section{Literature}

\subsection{Adolescent}

Sri Rumini and Siti Sundari (2004) suggested adolescence is the transition from childhood to adulthood that has developed all aspects or functions to adulthood. Adolescent is someone in his age has not been able to be responsible for themselves and their environment. The youth must prepare themselves to face these responsibilities are generally linked to the age of 12 years to 18 years old and unmarried. Ter Haar and Sastrawijaya (1997) adolescent still have not been able to master the functions of both physical and psychological.

Similarly, Papalia and Olds (2001), adolescence is a time of developmental transition between childhood and adulthood, which generally begins at age 12 or 13 years and ended at the age of late teens or early twenties. Singgih (1983) a adolescence was when observed closely will obtain special note as follows: 1) Starting seen the onset of physical changes, physical changes so rapidly and clearly different from the previous period. 2) The intellectual development leads to the thinking more about himself and a reflection himself. 3) Changes to the relationship between children and parents and others who are in the surrounding environment. 4) Changes in the demands and expectations of parents of teenagers. 5) The many changes in a short time, which poses problems in adjustment and efforts to integrate them.

Similarly, Purwanto (1999) Youth is a period of transition between childhood and adolescence. Often adolescence are faced with a confusing situation, on the one hand he has to behave like an adult and on the other hand he can not be said to be an adult. Growth and development are the two processes experienced by adolescence continuously. Growth and development are interconnected processes that can not be separated from the life of a adolescence.

Developmental tasks in adolescence by Havigurst (Hurlock, 1980) describes the adolescent developmental tasks as follows: relationship reached a new and more mature with peers both men and women; achieving social roles of men and women; receiving physical condition and use his body effectively; expect and achieve socially responsible behavior; prepare economic career; build intellectual skills and concepts needed as a good citizen; cultivate and acquire behaviors that are socially accountable; system obtain a set of values and ethics to guide behavior.

Biological Development; seen from the physical changes that occur in adolescents seen at the time of puberty, namely the increased height and weight as well as social maturity. According to Muss in Sunarto and Hartono (2002) describes that the physical changes that occur in girls, namely; the growth of bones, the body becomes high, limbs became long, grow breasts. Delicate feathers grow dark in the pubic, the body reaches maximum height growth annually, pubic hair into curly, menstruation or menstruation, grows feathers armpit.

Perry and Potter (2005) revealed that four major focus physical changes are: an increase in the speed of growth of the skeleton, muscles and viscera; sex-specific changes, such as changes in the shoulders and hips bees; changes in muscle and fat distribution; the development of the reproductive system and secondary sex characteristics.

Cognitive development; In cognitive development, adolescents are more abstract thinking than the children for example can complete abstract algebraic equations. Teens are also more idealistic in thinking as thinking about the ideal characteristics of self, others and the world. According to Piaget in Santrock (2003) in more real formal operational thinking is more abstract, idealistic, and logical.

Social development; Santrock (2003) revealed that the social transition adolescents experience changes in individual relationships with other human beings that is in emotion, personality, and the role of social context in the development. Potter and Perry (2005) say that the emotional changes during puberty and adolescence as dramatic as physical changes. This period is a period marked by the start of the responsibility and the assimilation of the community awards. At the time of adolescence, a person gain greater freedom and started to build its own identity. This makes adolescent identity crisis experienced shame, fear, and anxiety lead to impaired function at home and at school (Potter \& Perry, 2010).

Hurlock (2001) divided adolescence the based on gender, namely: 1) Adolescent of males; adolescence boys experience puberty between the ages of 14-17 years with signs, namely: a wet dream, the hair grows in armpits, chest and chin, not quickly carried away emotion, not quick to complain, not easily discouraged. 2) Adolescent of females; adolescent of females the experience of the puberty take place at the age of 12-15 years, with signs, namely: menarche (first menstruation), arise hair in the armpits and pubic, breast enlargement and hips. According Widyastuti (2009), there are several characteristics in adolescent development, namely: biological 
development, psychological development, cognitive development, moral development, spiritual development, and social development.

\subsection{Marriage}

According to Law No. 1 of 1974, definition of marriage is the bond inner and outer (Physical and mental) between a man and a woman as husband and wife with the intention of forming a family (household) are happy and everlasting based on almighty god. Basically marriage is a very sacred ritual. Each person must marry, overcome with happiness and hope the marriage that, happens for lifetime.

In the Al-Quran Surah An-Nur, verse 32, and marry people who alone among you, and the people who deserve (get married) from slave-slave you are a man and your slave servants are women. If they are poor God will enable them with His bounty. And Allah is vast (His gift), Knowing. From Surat an-Nur, verse 32 clearly states that marriage is one of the actions recommended by the religion, this is due to the existence of the marriage would prevent adultery, as well as other negative effects.

Sudarsono (1995), the purpose of marriage is to meet the demands of intent a human nature, relating between men and women in order to create a happy family based on love and affection to obtain offspring legitimate in society by following to rules that have been set by Islamic Shari'a. Islamic religion strongly encourages Muslims who are able to enter into marriage. Marriage in the Islamic religion is highly recommended. It was a way to channel of lawful and pure to channel the lust and passion through marriage than through adultery, prostitution, and so forth, the hated by God and very harmful.

In the Qur'an, letter of Ar-Rum verse 21, which means and in the between signs of His power is that he created for you wives of your kind alone, so you tend to be and feel at ease to him and made him a among you a sense of love and affection, Verily in this is truly there are signs for a people who think. Marriage is a relationship (contract) between men and women with the intention that each can enjoy another (istimtaa') and to establish a family sakinah and build a clean society (Utsaimin, 2009). Marriage in Act No. 1 of 1974, states that the ideal age for marriage at age 21 years, whereas a marriage going on at the age of 16 years for girls and 19 years for men. The according statutory Child Protection 23 In 2002, the marriage includings in the category of early marriage.

Mathur, Greene, and Malhotra (2003) also suggest some other causes that lead to early marriage. The causes are of among others, gender roles and the lack of alternatives. There are various reasons for a person to marry, such as on the basis of love, happiness, the desire to have a child, physical attraction, and the desire to get away from the unhappy situation (Hashmi et al., 2007).

Sarwono (1994), states that early marriage is common in puberty. This happens because a person is very vulnerable to sexual behavior. Sanderowitz and Paxman in Sarwono (1994) said that early marriage is also common for a person to think emotionally to do the marriage, they think should love each other and are ready to get married. Besides the causes of early marriage are an arranged marriage of parents, matchmaking is often caused by dropouts and due to economic problems.

In adolescence, marriage at a young age is considered as a way out to avoid casual sex. There also are doing it out of necessity and because pregnant out of wedlock. Adolescent sexual drive high, driven by the neighborhood association teenagers start permissive (like allow or permit) and almost without limit. In the end, the child is physically able to look more precocious and mature, but psychological, economic, religious, social, or other forms of self-reliance is not necessarily able to build a new community called family.

Marriage at a young age are particularly vulnerable overwritten because the problem is not yet stable level of emotional control. In a marriage will be encountered various problems that demand maturity in handling so that a marriage is not seen as mere material readiness, but also mental readiness and maturity to wade.

According Sampoerno and Anwar (1987) the negative impact of marriage at a young age in terms of his health is very poor for tool-human reproduction itself. Adolescents who marry young are required to build household and must be more independent than their peers who have the tasks of adolescent development before marriage. Adolescents who are married are expected not to get too hung themselves with their parents, but rather to their respective spouses.

Decision-making in this regard the decision to get married early occur also influenced by various factors or motives that encourage them to enter into marriage at such a young age; economic factors, factors of education, parental factors, factors themselves, as well as local cultural factors. 
Marriage performed by adolescents is often referred to as the early marriage. According Konopka (1976) early marriage is a marriage that began at age 16 and ending at age 20 years, or the still in school and categorized of adolescents. In Article 26 of Law No. 23 of 2002 on Child Protection, the parents are required to protect children from early marriage in this article, as laws marriage, without the provision of criminal sanctions so that these provisions almost no means to protect children from the threat of early marriage, early marriage is a noble bond to the bind two people of the opposite sex who was adolescents in to the family ties. There are various factors that encourage early marriage, namely: economic factors, educational factors, factors of parents, mass media factor, customs and cultural factors.

\section{Research Methods}

In this research, uses researcher quantitative research methods, through the descriptive analysis and inferential analysis. According Sugiyono (2012), quantitative research method can be interpreted as a research method that is based on the philosophy of positivism, used to examine the population or a particular sample. The sampling technique using simple random sampling technique. Making random sampling techniques to provide equal opportunities to the whole population to be sample in the study.

Analysis of quantitative data or statistics with the aim to test the hypothesis that has been set. According to Whitney (1960) the descriptive method is a fact-finding with a correct interpretation. According to Best (1982), descriptive research is a research method that attempted to describe the object or subject under study in accordance to the reality.

Thus the descriptive analysis aims to describe or search for and to learn about problems that occur in the life of society, regarding to certain situations, including in relationship of activities, attitude, outlook, and the influence of a phenomenon that occurs in the community. Interpretation of descriptive analysis as expressed by Nunnally (1978), namely: 1.01 to 2.00 mean scores (low); 2.01-3.00 (a simple, low); 3.01 to 4.00 (simple high); 4.01 to 5.00 (height).

Relating to methods of inferential, According Nisfiannoor (2009) inferential statistical methods is a method the dealing with data analysis on the samples to be used for generalizing to the population. Inferential statistics used are based on chance (probability) and a randomly selected sample (random). Inferential statistics help researchers to find out whether the results obtained from a sample can be generalized to the population (Creswell, 2008). To answer the question in this study the authors used T-test analysis, correlation analysis and regression analysis, before inferential analysis carried out first used analysis validity, reliability and normality of the data.

The population in this study is adolescent. The adolescent is a resident in the village Cireundeu, District East Ciputat, South Tangerang, Banten province of Indonesia, amounting to 453 people. According Sugiyono (2008), population is the generalization region consisting of the objects or subjects that have certain qualities and characteristics, established by researchers to learn and then be deduced. To facilitate these study researchers used a sample. According to Sugiyono (2008) sample is part of the number and characteristics possessed by this population. Samples used in this study of 150 people that is equal to $33 \%$ of the population. According to Arikunto (2008) Determination of Sample collection conducted if less than 100 better taken all until the research is the study of population. If a large number of subjects can be taken between $10-15 \%$ or $20-55 \%$ or more depending that is: 1) The ability of researcher views of time, effort and funds, 2) Narrow the vast area of observations of each subject, because it involves a lot or lack the funds, 3) Large or small risk borne by researchers for research risky, of course, if a sample of large (Many samples) the results will be better.

Data collection of research uses questionnaires. Sugiyono (2008) The questionnaire is a technique of data collection the done by giving a set questions or a written statement to the respondent to answer. In this study using an instrument with a Likert scale. Likert scale was used to measure corresponding views provided by respondents in a particular space in quest of a practice perceptions and attitudes (Cohen et al., 2000). In this study the instrument, respondents were asked to choose their retort to signify one of the numbers from 1 to 5 based explanation for the numbers-numbers that is Strongly Disagree (1) up to Strongly Agree (5).

In doing some research first researchers asked permission on the relevant parties to conduct research in the village Cireundeu, District East Ciputat, South Tangerang Banten province, as well as requesting data villagers Cireundeu, District East Ciputat, South Jakarta, in the collection of research data questionnaire given directly to the teenagers are being sampled in the study with the consent of the parents of teenagers, to include a license to conduct research on relevant parties.

Instrument indicator of adolescence based on the characteristics of adolescent development as mentioned by Widyastuti (2009), namely: biological development, psychological development, cognitive development, moral 
development, spiritual development, social development the number of items total 30 items. Indicator instrument marriage and law of marriage in Islam Ghozali (2003) revealed that: harmonious and terms of marriage, making a proposal and dowry marriage, prohibition and cancellation of marriage, agreement and trust in marriage, marriage from pregnancy outside of marriage and maintenance of children, polygamy and rights and obligations the number of 30 items total items. Before further study, then testing instrument to test the validity and reliability of the data of the research instrument, correlation of the items used to measure the validity of the data to measure the reliability of data by using the Alpha Cronbach index to measures the degree of confidence the items and aspects of assessment of instruments. Coefficient values is at the level of 0.3 (Pers, 1996) is used to determine the degree of validity of the assessment of instruments. Indices the used is cronbach alpha at the level 0.7 upwards (Pallant, 2001; Hair, 2010). The analisis validity and reliability of research can be seen in Table 1 .

Table 1 . Test validity and reliability study

\begin{tabular}{|c|c|c|c|c|}
\hline Variable & Indicator & Item & Correlation Value Item & Value Alfa \\
\hline \multicolumn{5}{|c|}{ Adolescent development } \\
\hline & Biological development, & 5 & $0.560-0.844$ & 0.773 \\
\hline & Psychological development, & 5 & $0.575-0.714$ & 0.764 \\
\hline & Cognitive development, & 5 & $0.622-0.780$ & 0.783 \\
\hline & Moral development, & 5 & $0.610-0.845$ & 0.779 \\
\hline & Spiritual development, & 5 & $0.634-0.758$ & 0.773 \\
\hline & Social development, & 5 & $0.603-0.835$ & 0.790 \\
\hline \multicolumn{5}{|l|}{ Marriage } \\
\hline & Pillars and terms of marriage, & 5 & $0.542-0.750$ & 0.758 \\
\hline & Making a proposal and marriage dowry, & 5 & $0.571-0.834$ & 0.767 \\
\hline & Prohibition and cancellation of marriage & 5 & $0.431-0.753$ & 0.763 \\
\hline & $\begin{array}{l}\text { Agreements and guardianship of } \\
\text { marriage, }\end{array}$ & 5 & $0.494-0.742$ & 7.17 \\
\hline & Pregnant mating and child maintenance, & 5 & $0.499-0.718$ & 0.732 \\
\hline & Polygamy and rights and obligations, & 5 & $0.441-0.772$ & 0.763 \\
\hline
\end{tabular}

From Table 1 the validity and reliability of data research note that the dimensions of biological development has a value of correlation between items of $r=0.560-0.844$, it has a cronbach alpha reliability index for dimensions of biological development of 0.773 . The dimensions of psychological development has a value of correlation between items of $r=0.575-0.714$, it has a cronbach alpha reliability index for dimensions of psychological development of 0.764 . The dimensions of cognitive development have a correlation between items of $\mathrm{r}=$ $0.622-0.780$, it has a cronbach alpha reliability index for dimensions of cognitive development of 0.783 . The dimensions of moral development has a value of correlation between item of $r=0.610-0.845$, it has a cronbach alpha reliability index for dimensions of moral development of 0.779 . The dimensions of spiritual development has a value of correlation between item of $r=0.634-0.758$, it has a cronbach alpha reliability index for dimensions of moral development of 0.773 . The dimension of social development has a value of correlation between items of $r=0.603-0.835$, it has a cronbach alpha reliability index for dimensions of social development of 0.790 .

The dimensions of the pillars and terms of marriage have a value of correlation between items of $r=0.542-0.750$, it has a cronbach alpha reliability index for dimensions of the pillars and terms of marriage of 0.758 . The dimensions of making a proposal and a marriage dowry have a value of correlation between items of $r=$ 0.571-0.834, it has a cronbach alpha reliability index for dimensions and making a proposal of marriage dowry of 0.767 . The dimensions prohibition and cancellation of marriage has a value of correlation between items of $r$ $=0.431-0.753$, it has a cronbach alpha reliability index for dimensions prohibition and cancellation of marriage of 0.763 . The dimensions agreements and guardianship of marriage has a value of correlation between items of $r$ $=0.494-0.742$, it has a cronbach alpha reliability index for dimensions agreements and guardianship of marriage 
of 0.717 . The dimensions pregnant mating and child maintenance has a value of correlation between items of $r=$ 0.499-0.718, it has a cronbach alpha reliability index for dimensions pregnant mating and child maintenance of 0.732 . The dimensions of polygamy and rights and obligations has a value of correlation between items of $r=$ $0.441-0.772$, it has a cronbach alpha reliability index for dimensions polygamy and rights and obligations of 0.763. From analysis of validity and reliability of the above it can be concluded that the overall dimensions of adolescent development and marriage have validity and reliability values are high. It can be used in advanced research studies. Furthermore, in the normality test, the results test normalitas research data on adolescent development and marriage can be seen in Table 2 .

Table 2. Research data normality test

\begin{tabular}{|c|c|c|c|c|c|}
\hline No. & Variable & Indicator & Value Normality & Sig. & Description \\
\hline \multirow[t]{7}{*}{1} & Adolescent development & & & & \\
\hline & & Biological development & 0.091 & 0.165 & Normal \\
\hline & & $\begin{array}{l}\text { Psychological } \\
\text { development }\end{array}$ & 0.121 & 0.255 & Normal \\
\hline & & Cognitive development, & 0.099 & 0.103 & Normal \\
\hline & & Moral development, & 0.087 & 0.203 & Normal \\
\hline & & Spiritual development, & 0.085 & 0.223 & Normal \\
\hline & & Social development, & 0.102 & 0.086 & Normal \\
\hline \multirow[t]{7}{*}{2} & Marriage & & & & \\
\hline & & Pillars and terms of marriage, & 0.101 & 0.094 & Normal \\
\hline & & $\begin{array}{l}\text { Making a proposal and } \\
\text { marriage dowry, }\end{array}$ & 0.072 & 0.415 & Normal \\
\hline & & $\begin{array}{l}\text { Prohibition and cancellation of } \\
\text { marriage }\end{array}$ & 0.099 & 0.109 & Normal \\
\hline & & $\begin{array}{l}\text { Agreements and guardianship } \\
\text { of Marriage }\end{array}$ & 0.121 & 0.253 & Normal \\
\hline & & $\begin{array}{l}\text { Pregnant mating and child } \\
\text { maintenance }\end{array}$ & 0.101 & 0.095 & Normal \\
\hline & & $\begin{array}{l}\text { Polygamy and rights and } \\
\text { obligations }\end{array}$ & 0.078 & 0.326 & Normal \\
\hline
\end{tabular}

Table 2, explains the results of tests of normality, it is known that variable adolescent development through dimension of biological development has a normality value of 0.091 with sig. 0.165 . The dimensions of psychological development have a normality value of 0.025 with sig. 0.255 . The dimensions of cognitive development have a normality value of 0.099 with sig. 0.103 . The dimensions of moral development have a normality value of 0.085 with sig. 0.203 . The dimensions of spiritual development have a normality value of 0.085 with sig. 0.223 . The dimension of social development has a normality value of 0.102 with sig. 0.086 . The data showed that, value the dimension of adolescent development eligible calculation normality test and declared the variable data of adolescent development is normal.

Normality test variables through dimension of pillars and terms of marriage have a normality value of 0.101 with sig. 0.094 . The dimensions of making a proposal and marriage dowry have a normality value of 0.072 with sig. 0.415. The dimensions of prohibition and cancellation of marriage have a normality value of 0.099 with sig. 0.109 . The dimensions of agreements and guardianship of marriage have a normality value of 0.121 with sig. 0.253 . The dimensions of pregnant mating and child maintenance have a normality value of 0.101 with sig. 0.095 . The dimensions of polygamy and the rights and obligations have a normality value of 0.078 with sig. 0.326 . The data showed that the overall dimensions of marriage in this study are in normal condition and can be used for further research.

\section{Research Result}

The research was conducted of adolescents in the village Cireundeu, District East Ciputat, South Tangerang, Banten province, the study sample amounts to 150 adolescents, ages ranged between 17-19 years, boys of 72 and girls of 78 people. Judging from the adolescents education level is seen that 107 adolescents attended high school and 43 adolescents were in a religious school. 


\subsection{Descriptive Analysis}

Descriptive analysis was conducted to determine the level of the stages of adolescent development and marriage. To determine the level of variable stages used descriptive analysis test. More descriptive statistical methods related to collecting and summarizing the data, as well as the presentation of the summary results of data. The descriptive analysis can be seen in Table 3 .

Table 3. Descriptive test data analysis research

\begin{tabular}{|c|c|c|c|c|c|}
\hline Variable & Indicator & $\mathrm{N}$ & Value Mean & $\begin{array}{l}\text { Value Standar } \\
\text { Deviation }\end{array}$ & Interpretation \\
\hline \multicolumn{6}{|c|}{ Adolescent development } \\
\hline & Biological development, & 150 & 17.81 & 3.140 & High \\
\hline & Psychological development, & 150 & 18.06 & 3.677 & High \\
\hline & Cognitive development, & 150 & 18.23 & 3.910 & High \\
\hline & Moral development, & 150 & 17.69 & 3.740 & High \\
\hline & Spiritual development, & 150 & 16.77 & 3.888 & High \\
\hline & Social development, & 150 & 18.67 & 3.268 & High \\
\hline \multicolumn{6}{|l|}{ Marriage } \\
\hline & Pillars and terms of marriage, & 150 & 16.99 & 3.202 & High \\
\hline & $\begin{array}{l}\text { Making a proposal and marriage } \\
\text { dowry, }\end{array}$ & 150 & 16.86 & 3.283 & High \\
\hline & $\begin{array}{l}\text { Prohibition and cancellation of } \\
\text { marriage, }\end{array}$ & 150 & 15.95 & 3.587 & High \\
\hline & $\begin{array}{l}\text { Agreements and guardianship of } \\
\text { marriage, }\end{array}$ & 150 & 16.14 & 3.362 & High \\
\hline & $\begin{array}{l}\text { Pregnant mating and child } \\
\text { maintenance, }\end{array}$ & 150 & 16.87 & 3.442 & High \\
\hline & $\begin{array}{l}\begin{array}{l}\text { Polygamy and rights and } \\
\text { obligations, }\end{array}\end{array}$ & 150 & 17.88 & 3.348 & High \\
\hline
\end{tabular}

From Table 3 above, the dimensions of biological development have a value of mean $=17.81, \mathrm{SD}=3.140$. The dimensions of psychological development have a value of mean $=18.06, \mathrm{SD}=3.677$. The dimensions of cognitive development have a value of mean $=18.23, \mathrm{SD}=3.910$. The dimensions of moral development have a value of mean $=17.69, \mathrm{SD}=3.740$. The dimensions of spiritual development have a value of mean $=16.77, \mathrm{SD}$ $=3.888$. For the dimension of social development have a value of mean $=18.67, \mathrm{SD}=3.268$. Variable marriage through the dimensions of the pillars and terms of marriage have a value of mean $=16.99, \mathrm{SD}=3.202$. The dimensions of making a proposal and dowry marriage have a value of mean $=16.86, \mathrm{SD}=3.283$. The dimensions of prohibitions and the cancellation of the marriage have a value of mean $=15.95, \mathrm{SD}=3.587$. The dimensions of trust agreement and marriage have a value of $16.14, \mathrm{SD}=3.362$. The dimensions of pregnant matting and child maintenance have a value of mean $=16.87, \mathrm{SD}=3.442$. The dimensions of polygamy, rights and obligations have a value of mean $=17.88, \mathrm{SD}=3.348$. The data shows that, variable of the adolescents development and marriage has a value that high-level. From these results indicate that the development of adolescents are in good condition, as well as education and young people have a good understanding of marriage as well.

\subsection{Inferential Analysis}

\subsubsection{Analysis of Test-T}

T-test analysis carried out to determine whether there are differences in adolescent development towards marriage, views of Gender. $T$ test analysis can be seen in Table 4. 
Table 4. Analysis test-t data adolescent development based on gender

\begin{tabular}{|c|c|c|c|c|c|}
\hline Indicator & $\mathrm{N}$ & Value Mean & S. Deviation & Value $\mathrm{t}$ & Value Sig \\
\hline Biological development & 150 & & & & \\
\hline Male & & 17.38 & 3.342 & -1.626 & -0.830 \\
\hline Female & & 18.21 & 2.907 & & \\
\hline Psychological development, & 150 & & & & \\
\hline Male & & 17.57 & 4.360 & -1.578 & -0.943 \\
\hline Female & & 18.51 & 2.864 & & \\
\hline Cognitive development, & 150 & & & & \\
\hline Male & & 17.99 & 4.137 & -0.723 & -0.463 \\
\hline Female & & 18.45 & 3.702 & & \\
\hline Moral development, & 150 & & & & \\
\hline Male & & 17.14 & 3.930 & -1.735 & -1.053 \\
\hline Female & & 18.19 & 3.505 & & \\
\hline Spiritual development, & 150 & & & & \\
\hline Male & & 16.65 & 3.835 & -0.364 & -0.232 \\
\hline Female & & 16.88 & 3.958 & & \\
\hline Social development, & 150 & & & & \\
\hline Male & & 18.96 & 2.943 & 1.026 & 0.548 \\
\hline Female & & 18.41 & 3.540 & & \\
\hline Adolescents in overall development, & 150 & & & & \\
\hline Male & & 17.61 & 13.714 & -1.465 & -2.973 \\
\hline Female & & 18.12 & 11.087 & & \\
\hline
\end{tabular}

*Significant at the level $p<0.05$

From Table 4, it can be known from the value variable adolescent development of the dimension biological development of $(\mathrm{t}=-1.626$; $\mathrm{Sig}=0.106)$. Overall value of biological development of male (mean $=17.38, \mathrm{SD}=$ 3.342 ) and the value of the biological development of female (mean $=18.21, \mathrm{SD}=2.907)$. It can be seen that there are differences in the biological development of the male with the female.

It can be seen the value variable adolescent development of the dimension psychological development of $(\mathrm{t}=$ -1.578; Sig $=0.117)$. Overall value of the dimension psychological development of male (mean $=17.57, \mathrm{SD}=$ 4.360 ) and the value of the dimension psychological development of female (mean $=18.51, \mathrm{SD}=2.864)$. It can be seen that there are differences in the psychological development of the male with female.

It can be seen the value variable adolescent development of the dimensions cognitive development of $(t=-0.723$; $\mathrm{Sig}=0.471)$. Value overall the dimension cognitive development of male (mean $=17.99, \mathrm{SD}=4.137)$ and the value the dimension cognitive development of female (mean $=18.45, \mathrm{SD}=3.702$ ). It can be seen that there are differences in the cognitive development of the male with the female and the average dimension of cognitive development male is lower than the average value female.

It can be seen the value variable adolescent development of the dimension moral development $(\mathrm{t}=-1.735$; $\mathrm{Sig}=$ $0.085)$. Overall value of dimension moral development of male (mean $=17.14, \mathrm{SD}=3.930)$ and the value of moral development of female (mean $=18.19, \mathrm{SD}=3.505)$. It can be seen that there is no difference of dimension moral development of male and female.

Knowable the variable adolescent development of the dimension the spiritual development $(t=-0.364$; $\mathrm{Sig}=$ 0.717). Overall value of spiritual development of male (mean $=16.65, \mathrm{SD}=3.835)$ and the value of spiritual development of female (mean $=16.88, \mathrm{SD}=3.958$ ). It can be seen that there is no difference in spiritual development of male and female.

Knowable variable values adolescent development of the dimension social development $(\mathrm{t}=-1.026$; Sig $=$ 0.306). Overall of value the dimension social development of male (mean $=18.96, \mathrm{SD}=2.943$ ) and the value the dimension social development of female (mean $=18.41, \mathrm{SD}=3.540$ ). It can be seen that there are differences in the social development of the male with the female.

It can be known the value of a variable overall adolescent development $(t=-1.465 ; \mathrm{Sig}=0.145)$. The value of the overall adolescent development of male $($ mean $=17.61, \mathrm{SD}=13.714)$ and the value of the overall 
development of female (mean $=18.12, \mathrm{SD}=11.087$ ). It can be seen that there are differences in the development of adolescent male with female and the average development of male at a value lower than the average female.

Table 5. Analysis of test-t data marriage by on gender

\begin{tabular}{|c|c|c|c|c|c|}
\hline Indicator & $\mathrm{N}$ & Value Mean & S. Deviation & Value $\mathrm{t}$ & Value Sig \\
\hline Pillars and terms of marriage & 150 & & & & \\
\hline Male & & 17.28 & 3.199 & 1.070 & 0.286 \\
\hline Female & & 16.72 & 3.203 & & \\
\hline Making a proposal and marriage dowry & 150 & & & & \\
\hline Male & & 16.74 & 3.552 & -0.443 & 0.659 \\
\hline Female & & 16.97 & 3.032 & & \\
\hline Prohibition and cancellation of marriage & 150 & & & & \\
\hline Male & & 16.12 & 3.580 & 0.562 & 0.575 \\
\hline Female & & 15.79 & 3.609 & & \\
\hline Agreements and guardianship of marriage & 150 & & & & \\
\hline Male & & 15.96 & 3.392 & -0.635 & 0.527 \\
\hline Female & & 16.31 & 3.347 & & \\
\hline Pregnant mating and child maintenance & 150 & & & & \\
\hline Male & & 16.64 & 3.420 & -0.805 & 0.422 \\
\hline Female & & 17.09 & 3.431 & & \\
\hline Polygamy and rights and obligations & 150 & & & & \\
\hline Male & & 18.06 & 3.206 & 0.616 & 0.539 \\
\hline Female & & 17.72 & 3.486 & & \\
\hline Overall Marriage & 150 & & & & \\
\hline Male & & 16.80 & 3.392 & 0.107 & 0.915 \\
\hline Female & & 16.77 & 3.351 & & \\
\hline
\end{tabular}

* Significant at the level $p<0.05$

From Table 5, it can be known from the value variable of the dimensions pillars and terms of marriage of $(\mathrm{t}=$ 1.070; $\mathrm{Sig}=0.286$ ). The value of the overall dimensions of the pillars and the terms marriage of male (mean $=$ $17.28, \mathrm{SD}=3.199)$. The value of the dimensions of the pillars and terms of marriage of female (mean $=16.72$, $\mathrm{SD}=3.203$ ). It can be seen that there are differences in dimension pillars and terms of marriage values of male and female.

It can be seen the value variable the dimensions making a proposal and marriage dowry of $(\mathrm{t}=-0.443$; $\mathrm{Sig}=$ $0.659)$. Value overall the dimensions of making a proposal and marriage dowry of male (mean $=16.74, \mathrm{SD}=$ 3.552 ) and the value dimension of making a proposal and marriage dowry of female (mean $=16.97, \mathrm{SD}=3.032$ ). It can be seen that there are differences in the dimensions making a proposal and marriage dowry of male and female and the average of dimensions making a proposal and marriage dowry of male more lower than the average value of female.

The variable value of marriage the dimension of prohibition and cancellation of marriage $(\mathrm{t}=0.562 ; \mathrm{Sig}=0.575)$. The value of the dimension prohibition and cancellation of marriage of female (mean $=15.79, \mathrm{SD}=3.609$ ). It can be seen that there are differences the dimensions of prohibitions and the cancellation of marriage of male and female, and the average the dimensions of the prohibitions and cancellation of marriage of male is higher of the average value of female. 
It can be seen value variable the dimensions agreements and guardianship of marriage $(t=-0.635$, Sig $=0.527)$. The value of the overall dimensions of the agreements and guardianship of marriage of male (mean $=15.96, \mathrm{SD}$ $=3.392$ ) and the value of the dimension agreements and guardianship of marriage of female (mean $=16.31, \mathrm{SD}$ $=3.347$ ). It can be seen that there are differences the dimensions of the agreements and guardianship of marriage of male and female.

It can be seen value variable the dimensions of pregnant mating and child maintenance $(t=-0.805 ; \mathrm{Sig}=0.422)$. Value overall dimensions of pregnant mating and child maintenance of male (mean $=16.64, \mathrm{SD}=3.420)$ and the value of dimension pregnant mating and child maintenance of female (mean $=17.09, \mathrm{SD}=3.431)$. It can be seen that there are differences the dimensions of pregnant mating and child maintenance of male and of female.

It can be seen value the variable marriage of dimensions polygamy and rights and obligations $(\mathrm{t}=0.616$; $\mathrm{Sig}=$ $0.539)$. Value overall dimensions of polygamy and rights and obligations of male (mean $=18.06, \mathrm{SD}=3.206)$ and the value dimension of polygamy and the rights and obligations of female (mean $=17.72, \mathrm{SD}=3.486)$. It can be seen that there are differences the dimensions of polygamy and rights and obligations of male and female.

It can be seen value of the variable of marriage overall is $(t=0.107 ; \mathrm{Sig}=0.915)$. The overall value of the variable of marriage of the gender male (mean $=16.80, \mathrm{SD}=3.392$ ) and the overall value of the variable of marriage of the gender female (mean $=16.77, \mathrm{SD}=3.351)$. It can be seen that there is no difference the overall value of the variable of marriage of gender male and female.

\subsection{Correlation Analysis}

Correlation analysis is used to examine the relationship between variables adolescent development and marriage. Relationship between the two variables can be seen in Table 6 .

Table 6. Correlation analysis research variables

\begin{tabular}{|c|c|c|c|c|c|c|c|c|c|}
\hline Adolescent development & Marriage & $\begin{array}{l}\text { Pillars and } \\
\text { terms of } \\
\text { marriage }\end{array}$ & $\begin{array}{l}\text { Making } \\
\text { proposal } \\
\text { and } \\
\text { marriage } \\
\text { dowry }\end{array}$ & $\mathrm{a}$ & $\begin{array}{l}\text { Prohibition } \\
\text { and } \\
\text { cancellation } \\
\text { of marriage }\end{array}$ & $\begin{array}{l}\text { Agreements } \\
\text { and } \\
\text { guardianship } \\
\text { of marriage }\end{array}$ & $\begin{array}{l}\text { Pregnant } \\
\text { mating and } \\
\text { child } \\
\text { maintenanc } \\
\mathrm{e}\end{array}$ & $\begin{array}{l}\text { Polygamy } \\
\text { and rights } \\
\text { and } \\
\text { obligation } \\
\mathrm{s}\end{array}$ & $\begin{array}{l}\text { Overall } \\
\text { marriage }\end{array}$ \\
\hline Biological development, & & $-.226^{* *}$ & -.018 & & -.060 & .097 & -.116 & -.095 & -.129 \\
\hline Psychological development, & & -.072 & -.078 & & .009 & .102 & $.163^{*}$ & -.050 & .026 \\
\hline Cognitive development, & & -.027 & -.128 & & .000 & .086 & .101 & -.030 & .002 \\
\hline Moral development, & & $-.175^{*}$ & $-.234 * *$ & & -.061 & -.021 & .098 & -.057 & -.137 \\
\hline Spiritual development, & & -.072 & -.101 & & .079 & .110 & .003 & .061 & .029 \\
\hline Social development, & & $-.167 *$ & -.109 & & .002 & -.010 & .029 & -.063 & -.096 \\
\hline Adolescent development, & & $-.205^{*}$ & $-.198 *$ & & -.006 & .107 & .088 & -.063 & -.081 \\
\hline
\end{tabular}

** Significant at the level $\mathrm{p}<0.01$

* Significant at the level $\mathrm{p}<0.05$

From Table 6 above, it appears that the relationship the variable of adolescent development through dimensions of biological development has a strong and negative relationship towards marriage on the dimensions of the pillars and the terms of marriage $(\mathrm{r}=-0.226)$. The dimensions of psychological development have a strong relationship and positive impact dimension of pregnant mating and child maintenance $(r=0.163)$. The dimensions of moral development has a strong and negative relationship to the dimensions of the pillars and the terms of marriage $(r=-0.175)$. The dimensions of making a proposal and a marriage dowry $(r=-0.234)$. Dimensions of social development has a strong and negative relationship to the dimensions of the pillars and the terms of marriage $(r=-0.167)$. The variable of adolescent development overall had a strong and negative relationship to the dimensions of the pillars and the terms of marriage $(r=-0.205)$. The dimensions of making a proposal and a marriage dowry $(\mathrm{r}=-0.198)$. The dimensions other the variabel of adolescents development has a low correlation to the dimensions of marriage and variable of marriage of the whole. It can be concluded that the variable of adolescents development have a low correlation with the variabel of marriage. $\mathrm{Tt}$ is seen the low value of the correlation of dimension adolescents development to dimension marriage and to the overall the variable of marriage. Thus it can be said that the development of the adolescents is not a major factor in the 
occurrence of early marriage among adolescents. From the results of these studies early marriages occur are caused by factors other than adolescent development.

\subsection{Regression Analysis}

Regression analysis used in this study is the plural regression analysis, multiple regression analysis was conducted to determine factors forecasters the relationship adolescent development and marriage. Relationship factor forecaster the variable adolescent development and marriage can be seen in Table 7 .

Table 7. Regression analysis variables in overall

\begin{tabular}{llllllll}
\hline \multicolumn{1}{c}{$\begin{array}{c}\text { Dimention Adolescent } \\
\text { development }\end{array}$} & \multicolumn{1}{c}{ B } & Beta $(\beta)$ & Nilai T & F & R & R2 & Sig \\
\hline (Constant) & 110.094 & & 14.213 & & & & \\
Biological development, & -.439 & -.128 & -1.469 & & & & \\
Psychological development, & .364 & .125 & 1.343 & & & & \\
Cognitive development, & .031 & .011 & .127 & 1.309 & 0.228 & 0.052 & 0.257 \\
Moral development, & -.440 & -.153 & -1.724 & & & & \\
Spiritual development, & .269 & .097 & 1.118 & & & & \\
Social development, & -.291 & -.088 & -.992 & & & & \\
\hline
\end{tabular}

From Table 7, it is known that the multiple regression calculation variable data adolescent development produces regression value the dimension of biologic development is -0.439 . The dimension of psychological development is 0.364 . The dimension of cognitive development is 0.031 . The dimension of moral development is -0.440 . The dimension of spiritual development is 0.269 . The dimension of social development is -0.291 . Constant value amounted is 110.094. From these results it can be concluded regression $\mathrm{Y}=110.094+-0.439 \mathrm{X}_{1}+0.364 \mathrm{X}_{2}+$ $-0.031 \mathrm{X}_{3}+-0.440 \mathrm{X}_{4}+0.269 \mathrm{X}_{5}+-0.291 \mathrm{X}_{6}$. The power of multivariate correlation between dimension of adolescent development and marriage to coefficient correlation is $\mathrm{R}=0.228$. These findings prove that the dimension of adolescent development has a relationship to marriage. With the value of $\mathrm{F}=1.309$, sig $=0.257$, $(\mathrm{p}<$ 0.005) show that the relationship has no significant relationship. The coefficient of determination between dimension of adolescent development and marriage is $\mathrm{R}^{2}=0.052$. This shows that only $5.2 \%$ variation that occurs in marriage can be influenced by the dimensions of adolescent development is the biological development, psychological development, cognitive development, moral development, spiritual development, and social development.

\section{Discussion of Results}

From the results of the study revealed that the adolescent development has a relationship and marriage. The relationships between two variables are included in the category low. The low relationship of variable the adolescent development and marriage be to evidence that the marriage is not influenced strongly by the adolescent development. Thus early marriage was not caused by the development of adolescents. From the research it appears that the adolescents development are in good condition, as well as education and young people have a good understanding of marriage as well. Adolescent development to be one factor in influencing the occurrence of marriage. In the adolescents development requires the mastery of science and technology in a certain capacity, as well as having emotional stability, social and personality, including against religious knowledge. The existence of religious knowledge in adolescent fortify them self of action or the juvenile delinquency including free sex.

Banten Province is a province that has a strong religious culture. This is evident from the customs prevailing in the society in Banten province including in rural Cireundeu, District East Ciputat, South Tangerang. So adolescents in the village Cireundeu, District East Ciputat, South Tangerang get a good religious education, thereby counteracting the association is not good or not in accordance with the norms prevailing in society.

From the results of the study also note that there are differences in the development of adolescent boys with a woman, and there is no difference in the overall variable seen early marriage of male sex with women. From these results it can be concluded that the development of adolescents in the village Cireundeu, District East Ciputat, South Tangerang have no differences, adolescents have a similar development between boys and girls. Similarly, marriage, adolescent understanding of marriage is very good, knowledge and understanding of adolescents to marriage indicates that adolescents have been prepared for the marriage. 
Marriage that occurs in adolescence are caused by promiscuity in they life, lack of religious knowledge on adolescent self to be one factor of deviant behavior committed by adolescence. The lack of understanding of religion causes adolescents choose behaviors that are socially less the valuable in the religious moral.

Free association is contrary to the norms of Islamic religion, the study in Indonesia showed that early marriage occurs as a solution to pregnancy outside of marriage (premarital pregnant) (Bannet, 2001; Gupta, 2000). Pregnancy outside of marriage is one of the negative impact of promiscuity. From research Munir (2003) presents the results of its analysis that early marriage becomes a necessity to cope with promiscuity that has hit adolescents. Munir considers that the conduct of early marriage is one of the anticipatory intimate relationships of government and religion was banned.

Pattern free sex in life (intercourse outside marriage) in adolescents there is a wrong action in violation of the norms and religion. It is estimated that each year the number of abortions in Indonesia reached 2.4 million people 800 thousand of which occurred among adolescents. These data released by the National Family Planning Coordinating Board in 2010 (Chomaria, 2011).

The research also found that adolescent development is not a major factor in the occurrence of marriage among adolescents. From these results marriages occur due to factors other than adolescent development. Based on research in various major cities in Indonesia, approximately 20 to 30 percent of adolescent said they had had sex. This free sex continues to step on to the level of marriage. Threats lifestyle free sex adolescent is generally good in the dormitory or boarding house seems to be growing more serious (Damayanti, 2012). Many factors influence adolescent attitudes toward premarital sex, including adolescent attitude itself, the attitude of the parents as well as the influence of social environment.

Adolescent sexual problem, are often worried parents, educators, government officials, experts and so on (Sarwono, 1997). Premarital sexual behavior according Sarwono (2010) is a behavior related to sexual drive along the opposite sex or the same sex performed before the ropes valid marriage either in law or religion.

Brown et al. (2006) in his study stating that adolescents uses media such as movies, music, magazines and television can influence the sexual behavior of adolescents. Media used teen has a lot of content in it any of the content contained in the media is the sexual content. Suryoputro et al. (2006) found that adolescent sexual behavior is influenced by three factors: personal factors such as lifestyle, age and social activities; environmental factors such as access and contact to the sources of information, value-norm in the environment, and socio-cultural; and behavioral factors such as sexual orientation, sexual experience, of the number partner, events abortion and condom uses. Adolescents who had premarital sexual behavior generally are adolescents who have the opportunity, do not get the proper knowledge about sexuality, the lack of attention from parents and social environment that is too free with their peers. Frappier in Anna (2011) describes the results of the survey that influence adolescent sexual behavior is the parents are made as role models, imitate his behavior and to follow celebrities. Planting religious values became one of the priorities in addressing the problem of promiscuity among adolescents.

\section{Conclusion}

From the results of the study showed that the development of adolescents have a low correlation to marriage, and it is known that the absence of differences in the development of adolescent males with female adolescent development, as well as marriage. The research note also of adolescent development is not a major factor marriage. From the studies it appears that the development of adolescents in good condition, adolescents have a good understanding and knowledge of the marriage. Marriage occurred among adolescents is one of lack of prevention and counseling to adolescents, the adolescents in need of understanding and knowledge on good relationships, relationships based on religious values, lack of understanding of the value of religion in adolescents causes promiscuity, free sex, as well as other behaviors that deviate from the teachings of religion. Ultimately To minimize free sex behaviors and prevention needs some assistance either from the government or from people nearby.

Adolescents needs a wide range of knowledge and guidance as well as skills in improving the quality of them, including an increase in personality and character that religious, religious knowledge on marriage is needed in adolescents, in order to provide an understanding and it can fortify themselves adolescents from the influence of promiscuity. The planting of religious knowledge within adolescents provide positive impact on the improvement of attitudes and adolescent personality, adolescent ignorance of the law and knowledge of marriage according to religious teachings can worsen socially the conducted everyday of adolescent. For that, to improve the quality of adolescents who have the knowledge, skills and behavior as well as good personality, takes the role of all levels of society, both within the family, neighborhood, and school environment. Religious education in adolescents must to be conducted if the wanted change of behavior and adolescent personality, to reduce promiscuity that occurred 
during this among teenagers, provide an understanding of marriage according to religious teachings to be one of the main focus to avoid marriages among adolescents.

\section{References}

Al-Migwar, M. (2006). Psikologi Remaja. Bandung: Pustaka Setia.

Anna, L. K. (2011). Remaja Tiru Perilaku Seksual Orang tua. Kompas.

Arikunto, S. (2008). Metodelogi penelitian. Yogyakarta: Bina Aksara.

Bennett, L. (2001). Single women's experiences of premarital pregnancy and induced abortion in Lombok, eastern Indonesia. Reproductive Health Matters, 9(17), 37-43. http://dx.doi.org/10.1016/S0968-8080(01)90006-0

Best, J. W. (1982). Metodologi Penelitian Pendidikan. Surabaya: Usaha Nasional.

BKKBN [Badan Kependudukan dan Keluarga Berencana Nasional]. (2011). Kajian Profil Penduduk Remaja (10-24 tahun).

Boykin, S. (2007). Successfull Teenage Marriage: A Qualitative Study of How Some Couples Have Made It Work. Virginia Polytechnic Institute and State university. Retrieved from http://www.findasticles.com

Brown, J. D., Kelly, L., Pardun, C. J., Guo, G., Kenneavy, K., \& Jackson, C. (2006). Sexy Media Matter, Exposure to Sexual Content in Music, Movies, Television, and Magazines Predicts Black and White Adolescents Sexual Behavior. Pediatrics.

Choe, K. M., Thapa, S., \& Achmad, S. I. (2007). Early Marriage and Childbearing in Indonesian and Nepal. Usaid organization. Retrieved from http://www.usaid.org/draft/html

Chomaria, N. (2011). Saat Anakku Remaja. Solo: Tinta Media.

Cohen, L., Manion, L., \& Morrison, K. (2000). Research Methods in Education (5th ed.). London: Routledge Falmer. http://dx.doi.org/10.4324/9780203224342

Creswell, J. W. (2008). Educational Researchs: Planning, Conducting, and Evaluating Quantitative and Qualitative Research. New Jersey: Pearson Education Inc.

Damayanti, N. (2012). Buku Pintar Panduan Bimbingan dan Konseling Islam. Yogyakarta: Araska.

Darajad, Z. (1995). Remaja Harapan dan Tantangan. Jakarta: Ruhana.

Ghozali, A. R. (2003). Fiqh Munakahat. Jakarta: Kencana Prenada Media Group.

Gupta, N. (2000). La formation des unions chez les adolescentes du Nordeste (Bresil) ("The formation of adolescent unions in northeast Brazil."). Cahiers Quebecois de Demographie, 29(2), 287-306. http://dx.doi.org/10.7202/010289ar

Hair, J. F. (2010). Multivariat data analysis (Edisi ke-6). New Jersey: Pearson Educational International.

Hashmi, K., \& Hassan. (2007). Marital Adjustment, stress and depression among working and non-working married women. Internet journal of medical. Retrieved from http: //www.geocities.com/ agnihotrimed/peper02jan-jun2007

Hurlock, E. (2001). Psikologi Perkembangan. Jakarta : Erlangga.

Hurlock, E. B. (1980). Psikologi perkembangan suatu pendekatan sepanjang rentang kehidupan (Edisi terjemahan). Jakarta : Erlangga.

Hurlock, E. B. (1999). Psikologi Perkembangan Suatu Pendekatan Sepanjang Rentang Kehidupan (Terjemahan oleh Istiwidayanti dan Soedjarwo). Jakarta: Penerbit Erlangga.

Konopka, G. (1976). Young Girls, a Portrait of Adoles-cence. New York: Englewood Clifft, Prentice-Hall.

Mathur, G. M. (2003). Too Young too Wed (The Lives, Rights, and Health of Young Married Girls). International Center for Research on Women (ICRW).

McIntyre, P. (2006). Married Adolescent: No Place of Safety. Geneva: WHO Document Productionn Services.

Munir, A. (2003). Pernikahan Dini di Yogyakarta dan Perspektif Masyarakat Dari Tahun 2001-2003 Dalam Perspektif Hukum Islam. Yogyakarta: LKiS.

Monks, F. J., Knoers, A. M. P., \& Haditono, S. R. (2001). Psikologi Perkembangan: Pengantar dalam Berbagai Bagiannya. Yogyakarta: Gajah Mada University Press.

Nisfiannoor, M. (2009). Pendekatan Statistika Modern untuk Ilmu Sosial. Jakarta : Salemba Humatika. 
Nunally, J. C. (1978). Psychometric Theory. New York: McGraw-Hll Book.

Pallan, J. (2001). SPSS Survival manual: A Step by step guide to data analysis using SPSS. New Sydney, Australia: Allen \& Unwin.

Papalia, D. E., \& Olds, S. W. (1995). Human Development (6th ed.). New York: McGraw-Hill.

Papalia, D. E., Feldman, R. D., \& Olds, S. W. (2001). Human Development. New York: McGraw Hill.

Pers, L. S. (1996). Statistical analysis for educatioan and psycology Researchs. London: The Falmers Press.

Poerwadarminta. (1984). Kamus Umum Bahasa Indonesia. Jakarta: Depdiknas.

Potter, P. A., \& Perry, A. G. (2005). Fundamental Keperawatan (Vol. 1). Jakarta: EGC.

Potter, P. A., \& Perry, A. G. (2010). Fundamental Keperawatan Buku 2. Jakarta: Salemba Medika.

Purwanto. (1999). Pengantar Perilaku Manusia Untuk Keperawatan. Jakarta: EGC.

Riskesdas. (2010). Pernikahan dini Pada Beberapa Provinsi di Indonesia: Dampak Overpopulation, Akar Masalah dan Peran Kelembagaan di Daerah. BKKBN.

Ritonga, R. (1997). Statistika untuk Penelitian Psikologi dan Penelitian. Jakarta: Lembaga Penerbit Fakultas Ekonomi UI.

Rumini, S. S. (2004). Perkembangan Anak dan Remaja. Jakarta: PT Rineka Cipta.

Sampoerno, D., \& Azwar, A. (1987). Perkawinan dan kehamilan pada wanita usia muda. Jakarta: Ikatan Ahli Kesehatan Masyarakat Indonesia.

Santrock, J. W. (2003). Adolescence. Perkembangan Remaja. Edisi Keenam, Jakarta: Erlangga.

Sarwono, S. W. (1994). Perkawinan remaja. Jakarta : PT. Raja Grafindo Persada.

Sarwono, S. W. (2010). Psikologi Remaja, Edisi Revisi. Jakarta: Rajawali Press.

Sarwono, S. (1997). Psikologi Remaja. Jakarta: Raja Grafindo.

Singgih, G. D. (1983). Psikologi Perkembangan Anak dan Remaja. Jakarta: BPK Gunung Mulia.

Soetjiningsih. (2004). Pertumbuhan Somatik Pada Remaja. Jakarta: Sagung Seto.

Sudarsono. (1995). Kenakalan Remaja. Jakarta: Rineka Cipta.

Sugiyono. (2008). Metode Penelitian Bisnis. Bandung, Pusat Bahasa Depdiknas.

Sugiyono. (2012). Penelitian Kualitatif Kuantitatif. Bandung: Alfabeta.

Sunarto dan Hartono, B. A. (2002). Perkembangan Peserta Didik. Jakarta: PT Rineka Cipta.

Suryoputro, A., Ford, A. J., \& Shaluhiya, Z. (2006). Faktor-Faktor yang Mempengaruhi Perilaku Seksual Remaja di Jawa Tengah Implikasinya terhadap Kebijakan dan Layanan Kesehatan Seksual dan Reproduksi [internet]. JMAKARA, 10(1), 29-40.

Ter Haar, B. Z. N., \& dan Sastrawijaya, S. (1997). Beberapa Masalah Tentang Kenakalan Remaja. Bandung: PT. Karya Nusantara.

Undang-Undang Republik Indonesia Nomor 1 Tahun 1974 Tentang Perkawinan (n.d.). Jakarta: PT Rineka Cipta.

Undang-Undang Republik Indonesia Nomor 23 Tahun 2002. Tentang Perlindungan Anak (n.d.). Jakarta: PT Rineka Cipta.

UNICEF. (2001). A league table of teenage births in rich nations. UNICEF Innocenti Research Centre, Florence.

UNICEF. (2011). Multiple Indicator Cluster Surveys-Available Report/Datasets by Country. Retrieved from http://www.childinfo.org/mica-available.html

Utsaimin. (2009). Dasar Hukum Hidup Berumah Tangga. Surabaya: Risalah Hati.

Whitney, F. L. (1960). The Elements of Resert. Osaka: Overseas Book Co.

WHO. (2006). Using Human Rights for Maternal and Neonatal Health: A Tool for Strengthening Laws. Policies and Standards of Care: A Report, Geneva.

Widyastuti, Y. et al. (2009). Kesehatan Reproduksi. Jakarta: Fitramaya. 


\section{Copyrights}

Copyright for this article is retained by the author(s), with first publication rights granted to the journal.

This is an open-access article distributed under the terms and conditions of the Creative Commons Attribution license (http://creativecommons.org/licenses/by/3.0/). 